\title{
Analisis Penggunaan Tanda Baca Dan Hurup Kapital Dalam Karya Surat Siswa
}

\author{
Fikran Fadli $^{1}$, Nasaruddin ${ }^{2}$, Siti Rohana Hariana Intiana ${ }^{3}$ \\ ${ }^{1}$ Pendidikan Guru Sekolah Dasar, Fakultas Keguruan dan Ilmu Pendidikan, Universitas Mataram, Jl. \\ Majapahit No. 62, Mataram 83115 \\ Email: fikranfadli@gmailcom
}

\begin{abstract}
Abstrak: Tujuan penelitian ini adalah untuk menganalisis kemampuan siswa dalam menggunakan tanda baca dan huruf capital dalam karya surat siswa kelas V SDN Jelenga. Penelitian ini menggunakan metode kualitatif deskriptif yaitu dengan mengkaji dan menganalisis data secara objektif berdasarkan fakta nyata yang ditemukan di lapangan. Hasil temuan dipaparkan secara deskriptif, melalui analisis isi dari karya surat ini sehingga ditemukan kesalahan penulisan yang dibuat oleh siswa khususnya kesalahan dalam penulisan huruf kapital dan tanda baca. Hasil penelitian menunjukkan pada penulisan huruf kapital, kesalahan terbesar yang paling sering dilakukan siswa yaitu pada penulisan huruf pertama kata awal kalimat dengan persentase 43,4\%. Pada tanda baca kesalahan terbesar yaitu pada penghilangan tanda titik pada akhir kalimat yang bukan pertanyaan/seruan dan penghilangan tanda koma yang dapat dipakai untuk menghindari salah baca/salah pengertian dengan persentase $40 \%$. Faktor yang menyebabkan siswa melakukan kesalahan pada penulisan huruf kapital dan tanda baca, yakni disebabkan karena motivasi belajar siswa rendah, respon dan sikap siswa yang kurang baik selama proses belajar, guru yang hanya menghandalkan metode ceramah dan lebih menekankan aspek teoretikal dari pada keterampilan praktis bahasa tulis, dan materi ajar yang kurang dipahami siswa.
\end{abstract}

\section{Kata Kunci: Penggunaan Tanda Baca, Hurup Kapital, Karya Surat}

\section{PENDAHULUAN}

Pembelajaran bahasa Indonesia di sekolah dasar merupakan proses pembelajaran yang dilakukan secara terpadu (Shara, 2019). Hal ini dilakukan untuk meningkatkan kemampuan peserta didik dalam melakukan komunikasi menggunakan bahasa Indonesia dengan baik dan benar baik secara lisan maupun tulisan (Shara, 2019). Pembelajaran bahasa Indonesia terdiri dari aspek mendengarkan, berbicara, membaca, dan menulis (Yanti et al., 2016).

Kesalahan berbahasa merupakan penyimpangan dari faktor-faktor penentu komunikasi dan kaidah tata bahasa yang berlaku, khususnya bahasa Indonesia (Ariyanti, 2019). Penggunaan kalimat dalam berbahasa baik secara lisan maupun tertulis harus lengkap. Kalimat yang lengkap tersebut harus ditulis sesuai dengan aturan-aturan Pedoman Umum Ejaan Bahasa Indonesia (PUEBI) (Ariyanti, 2019).
Saat ini, penggunaan huruf kapital (besar) mulai jarang diperhatikan penggunaannya dalam kehidupan sehari-hari, salah satunya adalah penggunaan secara tertulis di instansi (Siburian, 2018). Bahkan kaidah penggunaanya pun seringkali dilupakan oleh penulis (Ariyanti, 2019). Hal yang sama juga terjadi pada penggunaan tanda baca. Seringkali penggunaan tanda baca banyak yang keliru dalam penggunaanya.

Permasalahan penggunaan tanda baca dan huruf kapital dalam karya surat siswa Kelas V khusus di kelas V SDN jelenga merupakan permasalahan yang menarik untuk diteliti. Hal itu berkenaan dengan keinginan untuk mengetahui kesalahan penggunaan tanda baca dan huruf kapital dalam karya surat siswa kelas V SDN Jelenga, serta untuk mencari solusi dalam mengurangi kesalahan penggunaan tanda baca dan huruf kapital dalam karya surat siswa kelas V SDN Jelenga. 


\section{METODE}

Penelitian ini menggunakan metode kualitatif deskriptif. Penelitian ini berupaya untuk menganalisis isi dari karya surat siswa kelas V SDN Jelenga yang telah dibuat siswa, dimana dilakukan analisis terhadap kesalahan penulisan huruf kapital dan tanda baca. Oleh karena itu, metode deskriptif kualitatif ini dipandang sesuai untuk mengkaji dan menganalisis data secara objektif berdasarkan fakta nyata yang ditemukan di lapangan. Kemudian dipaparkan secara deskriptif, melalui analisis isi dari karya surat ini sehingga ditemukan kesalahan penulisan yang dibuat oleh siswa khususnya kesalahan dalam penulisan huruf kapital dan tanda baca.

\section{HASIL DAN PEMBAHASAN}

\section{Hasil data kesalahan penulisan huruf kapital}

Jumlah kesalahan dalam karya surat pada penulisan huruf capital disajikan dalam bentuk persentase sebagai berikut: (1) Kode 1 yaitu kesalahan penulisan huruf pertama nama khas geografi sebesar 4,34\%; (2) Kode 2 yaitu kesalahan penulisan huruf kapital pada huruf pertama awal kalimat sebesar 43,4\%; (3) Kode 3 yaitu kesalahan penulisan huruf kapital dipertengahan kata kalimat sebesar 21,7\%; (4) Kode 4 yaitu kesalahan penulisan huruf kapital disetiap kata dalam kalimat sebesar 0\%; (5) Kode 5 kesalahan penulisan huruf pertama dalam ungkapan yang berhubungan dengan hal hal keagamaan kitab suci, nama Tuhan (kata ganti untuk Tuhan) sebesar 0\%; (6) Kode 6 yaitu penulisan huruf pertama nama tahun, bulan, hari raya, dan peristiwa sejarah sebesar $4,34 \%$; dan (7) Kode 7 yaitu penulisan huruf pertama kata petunjuk hubungan kekerabatan $\times 100=26 \%$.

Berdasarkan presentase diatas, dapat dilihat bahwa kode 4 dan 5 memilliki presentase terkecil sedangkan kode 2 dan 7 memiliki presentase terbesar. Beberapa faktor yang menyebabkan kesalahan pada penulisan huruf kapital dengan presentase terkecil dan terbesar yaitu:
1) Kesalahan Terkecil

Kesalahan terkecil ditemukan pada aspek kode 4 dan 5 yang masing- masing memiliki persentase $0 \%$. Kode 4 kesalahan menulis huruf kapital disetiap kata dalam kalimat. Kode 5 kesalahan penulisan huruf pertama dalam ungkapan yang berhubungan dengan hal-hal keagaaman (terbatas pada nama diri) kitab suci, tuhan, dan termasuk kata ganti untuk tuhan. Berdasarkan tulisan siswa yang telah dianalisis, kesalahan kode 4 dan 5 terkecil karena penulisan huruf kapital ini sangat jarang digunakan dalam tulisan siswa dalam karya surat. Karena dari tulisan siswa terutama untuk kata yang menunjukan nama tahun, bulan, dan hari raya tidak ditemukan, begitu pula kesalahan penulisan huruf pertama dalam ungkapan yang berhubungan dengan hal-hal keagaaman (terbatas pada nama diri) kitab suci, tuhan, dan termasuk kata ganti untuk tuhan tidak ditemukan pada karya surat siswa SDN Jelenga.

2) Kesalahan Terbesar

Dapat dilihat dari persentase kesalahan pada kode 2, yaitu penulisan huruf kapital pada huruf pertama awal kalimat memiliki kesalahan cukup besar yakni sebesar \%. Berdasarkan tulisan siswa yang telah dianalisis, kesalahan tersebut terlihat pada pemulaan kalimat, baik awal kalimat maupun pergantian kalimat. Beberapa kesalahan penulisan huruf kapital pada awal kalimat banyak terjadi pada saat siswa menuliskan kalimat baru (pergantian kalimat), kesalahan ini tidak akan terjadi apabila siswa memperhatikan penghentian kalimat yang ditandai dengan intonasi titik (.). Dengan kata lain bahwa setelah penghentian kalimat siswa harus memulainya dengan huruf kapital. Ada beberapa indikasi mengapa kesalahan pada penulisan huruf pertama awal kalimat ini masih sering terjadi kesalahan. Pertama, adanya keterbiasaan dari siswa itu sendiri. Maksudnya keterbiasaan siswa saat pergantian kalimat seringkali menulisnya 
dengan huruf kecil pada huruf pertama kata dalam kalimat padahal seharusnya ditulis dengan huruf kapital. Kedua, siswa tidak terlatih menulis huruf kapital pada huruf pertama awal kalimat.

\section{Hasil data kesalahan penggunaan tanda baca}

Jumlah kesalahan dalam karya surat pada penulisan huruf kapital disajikan dalam bentuk persentase sebagai berikut: (1) Kode A yaitu kesalahan penghilangan tanda koma yang dapat dipakai untuk menghindari salah baca/salah pengertian sebesar 40\%; (2) Kode B yaitu penghilangan tanda koma untuk memisahkan anak kalimat dari induk kalimat jika anak kalimat itu didahului induk kalimat sebesar 20\%\%; (3) Kode C yaitu pengilangan tanda koma diantara unsur unsur dalam suatu perincian atau pembilang sebesar 0\%; (4) Kode D yaitu penghilangan tanda koma dibelakang/ungkapan penghubung antar kalimat yang terdapat pada awal kalimat seperti oleh karena itu, jadi, meskipun, saat itu, namun, dll sebesar 0\%. (5) Kode E yaitu penghilangan tanda koma untuk memisahkan kalimat setara berikutnya yang didaului oleh kata tetapi, sedangkan, melainkan, dll sebesar 0\%; (6) Kode F yaitu penghilangan tanda titik pada akhir kalimat yang bukan pertanyaan atau sapaan sebesar 40\%; dan (7) kode G yaitu penghilangan tanda titik untuk memisahkan angka jam, menit dan detik yang menunjukan waktu $0 \%$.

Berdasarkan presentase diatas, dapat dilihat bahwa kode $\mathrm{C}, \mathrm{D}, \mathrm{E}$ dan $\mathrm{G}$ memiliki presentase terkecil sedangkan kode A dan F. Berikut akan disampaikan beberapa faktor yang menyebabkan kesalahan pada penulisan huruf kapital dengan presentase terkecil dan terbesar. Pembatasan ini dilakukan karena begitu banyak dan beragamnya jenis aspek kesalahan pada penulisan huruf kapital sehingga penulis hanya memilih dua kesalahan dengan presentase terkecil dan terbesar.

1) Kesalahan Terkecil

Kesalahan terkecil ditemukan pada aspek kode C, D, E dan G. Kode C Penghilangan tanda koma diantara unsur-unsur dalam suatu perincian atau pembilang. Kode D Penghilangan tanda koma dibelakang kata/ungkapan penghubung antar kalimat yang terdapat pada awal kalimat seperti oleh karena itu, jadi, meskipun, saat itu, namun, dll. Kode E yaitu penghilangan tanda koma untuk memisahkan kalimat setara berikutnya yang didahului oleh kata tetapi, sedangkan, melainkan, dll sedangkan kode G yaitu penghilangan tanda titik untuk memisahkan angka jam, menit, dan detik yang menunjukan waktu. Kode C, D, E dan G memiliki persentase sama yaitu $0 \%$. Hal ini terjadi karena dari berbagai tulisan siswa yang telah dianalisis tanda baca ini tidak digunakan

2) Kesalahan Terbesar

Berdasarkan persentase dapat dilihat kesalahan terbesar terdapat pada kode A dan F yaitu penghilangan tanda titik diakhir kalimat, sebanyak $40 \%$. Berdasarkan tulisan siswa yang telah dianalisis, siswa yang melakukan kesalahan pada penghilangan tanda titik diakhir kalimat, dapat diketahui ada beberapa indikasi kesalahan ini terjadi pertama, ketidaktelitian siswa setelah akhir kalimat tidak menggunakan tanda titik, padahal sesuai kaidah kebahasaan yang baik dan benar setelah akhir kalimat menggunakan tanda titik dan titik. Kedua, ketidaktahuan beberapa siswa akan penempatan tanda titik ketika akhir kalimat.

\section{KESIMPULAN}

Berdasarkan kajian teoretis dan hasil penelitian yang telah dilakukan maka disimpulkan bahwa: (1) Berdasarkan 17 tulisan siswa yang telah dianalisis, pada penulisan huruf kapital, kesalahan terbesar yang paling sering dilakukan siswa yaitu pada penulisan huruf pertama kata awal kalimat dengan persentase $43,4 \%$. Kesalahan tersebut terlihat pada pemulaan kalimat, baik awal kalimat maupun pergantian kalimat. Indikasinya Pertama, adanya keterbiasaan dari siswa itu sendiri. 
Kedua, siswa tidak terlatih menulis huruf kapital dengan baik dan benar; (2) Pada tanda baca kesalahan terbesar yaitu pada penghilangan tanda titik pada akhir kalimat yang bukan pertanyaan/seruan dan penghilangan tanda koma yang dapat dipakai untuk menghindari salah baca/salah pengertian dengan persentase $40 \%$. Indikasinya pertama, adanya ketidaktelitian siswa. Kedua, ketidaktahuan siswa akan penempatan tanda titik akhir kalimat. (3) Faktor lain yang menyebabkan siswa melakukan kesalahan pada penulisan huruf kapital dan tanda baca, yakni disebabkan karena motivasi belajar siswa rendah, respon dan sikap siswa yang kurang baik selama proses belajar, guru yang hanya menghandalkan metode ceramah dan lebih menekankan aspek teoretikal dari pada keterampilan praktis bahasa tulis, dan materi ajar yang kurang dipahami siswa.

\section{DAFTAR PUSTAKA}

Ariyanti, R. (2019). Analisis Kesalahan Penggunaan Huruf Kapital, Tanda Baca, dan Penulisan Kata pada Koran Mercusuar. Jurnal Bahasa Dan Sastra, 4(4), $\quad$ 12-28. http://jurnal.untad.ac.id/jurnal/index.ph p/BDS/article/view/12178/9361

Shara, A. (2019). Analisis Kemampuan Menentukan Huruf Kapital Dan Tanda Baca Pada Karangan Deskripsi Siswa Kelas V Sd Negeri 161 Pekanbaru. Jurnal PAJAR (Pendidikan Dan Pengajaran), 3(2), 346-352.

Siburian, L. (2018). Analisis Kesalahan Penulisan Huruf Kapital Oleh Mahasiswa Pgsd Semester Ii Kelas 3 Unika Santo Thomas Sumatera Utara. School Education Journal Pgsd Fip Unimed, $\quad 8(1), \quad 81-87$. https://doi.org/10.24114/sejpgsd.v8i1.9 821

Yanti, N., Suhartono, \& Kurniawan, R. (2016). Penguasaan Materi Pembelajaran Keterampilan Berbahasa Indonesia Mahasiswa S1 Program Studi
Pendidikan Bahasa Dan Sastra Indonesia FKIP Universitas Bengkulu. Jurnal Ilmiah Korpus, 2(1), 72-82. 